\author{
Н.В. Бахур, головний консультант \\ відділу регіональної політики \\ Національний інститут стратегічних досліджень
}

\title{
Фіскальна стабільність місцевих бюджетів у контексті адміністрування акцизного податку з роздрібної реалізації тютюнових виробів
}

\author{
(Представлено: д.е.н., проф. Шимаєва Л.Г.)
}

\begin{abstract}
Акцизний податок з роздрібної реалізації тютюнових виробів займає важливе місце в складі додаткових податкових надходжень громад. Цей податок дозволяє швидко наповнювати дохідну частину місиевих бюджетів та може бути направлений на потреби громад. Важливою складовою бюджетної системи краӥни є місиеві бюджети. Причиною розбалансованості бюджетної системи може бути зміна умов формування $i$ виконання місиевих бюджетів. Фінансова основа місиевих бюджетів - доходи. Має бути забезпечено справедливий розподіл ресурсів між бюджетами місиевого самоврядування. Дуже важливо підвищувати податкову культуру платників податків. Цей чинник також впливає на наповнення місиевих бюджетів. Також необхідно запобігати незаконному обігу підакиизних товарів та допомагати контролюючим органам у своєчасному виявленні таких фактів. Для збільшення обсягів надходження до місиевих бюджетів та забезпечення конкурентного середовища тютюнового ринку необхідним є удосконалення адміністрування акцизного податку з роздрібної реалізаціі тютюнових виробів. Проаналізовано вплив акцизного податку з роздрібної реалізації тютюнових виробів на формування дохідної частини місцевих бюджетів та ситуацію з його можливою відміною. Запропоновано рекомендації щзодо покращення умов адміністрування акцизного податку з роздрібної реалізачії тютюнових виробів, а також иляхи боротьби з нелегальною реалізацією иієї продукції для забезпечення контролю за своєчасною сплатою ицього податку: удосконалити порядок сплати акциизого податку з роздрібної торгівлі тютюнових виробів до місиевих бюджетів, вжити заходів щодо запуску автоматизованої системи «Електронна акцизна марка», ухвалити план заходів з реалізаиї Стратегії у сфері протидії незаконному виробництву та обігу тютюнових виробів на період до 2021 року.
\end{abstract}

Ключові слова: акциизний податок; директиви СС; розбалансованість; місцевий бюджет; нелегальний продаж.

Актуальність теми. 3 точки зору фіскальної ролі оподаткування тютюновий ринок $є$ важливим для України. В умовах дефіциту фіскальних ресурсів акцизний податок з роздрібної реалізації тютюнових виробів займає помітне місце в дохідній частині місцевих бюджетів.

Аналіз останніх досліджень та публікації, на які спирається автор. Дослідженням питання акцизного оподаткування та специфічного акцизного оподаткування присвячено публікації О.В. Озерчука [8], В.І. Коротуна [2], В.Л. Андрущенка, О.Д. Данілова, А.Б. Дриги, В.І. Лютого, В.М. Опаріна [9], В.М. Федосова [10], С.І. Юрія [10]. Також це питання вивчалося Асоціацією міст України [1].

Мета статті - дослідити вплив акцизного податку з роздрібної реалізації тютюнових виробів на наповнення місцевих бюджетів.

Викладення основного матеріалу. Згідно з Бюджетним кодексом України, акцизний податок 3 реалізації суб'єктами господарювання роздрібної торгівлі підакцизних товарів зараховується до бюджетів об'єднаних територіальних громад і міських бюджетів. У Податковому кодексі України передбачено поетапне підвищення ставок цього податку. У 2019 р. вже відбулося підвищення ставки акцизного податку на тютюнові вироби: з 01.01.2019 р. (на 20 \%) та з 01.07.2019 р. на 9 \%. Згідно з Законом України № 2628VIII від 22.05.2019 р. «Про внесення змін до Податкового кодексу та деяких інших законодавчих актів України щодо покращення адміністрування та перегляду ставок окремих податків і зборів», мінімальне акцизне податкове зобов'язання зі сплати акцизного податку 3 тютюнових виробів станом на 1 січня 2019 р. для цигарок без фільтру та з фільтром за 1000 штук становило 927,84 грн, а 31 липня вже становить 1011,35 грн. Також цим законом передбачається збільшення ставки акцизного податку на тютюнові вироби на 31 \% у 2020 р. і на 57 \% у 2021 р. (порівняно зі ставкою станом на початок 2019 року). Фінансова спроможність громад підсилюється відповідним збільшенням надходжень від цього виду податку через поповнення загального фонду місцевих бюджетів.

Підвищення ставок акцизного податку з роздрібної реалізації тютюнових виробів не кореспондує зі статтею 1 Директиви Ради 2008/118/СС. Існує суперечність із вимогами Директиви ЄС. Можна оподатковувати іншими непрямими податками «гармонізовані» підакцизні товари (п. 2) та послуги 3 
продажу підакцизних товарів (п. 3). Але роздрібний акциз в Україні не має законодавчо встановленого цільового призначення і не є податком, пов'язаним із послугою продажу. Також механізм справляння роздрібного акцизу пов'язаний із високим ризиком податкових зловживань. Досить часто такі випадки стаються через те, що реалізацію підакцизних товарів здійснюють дрібні торгівці. За оцінками фахівців Університету Державної фіскальної служби України, об'єктивною є потреба у відмові від акцизу 3 роздрібного продажу на користь підвищення ставок «стандартного» акцизного податку (специфічних ставок оподаткування для тютюнових виробів). Ініціатива щодо роздрібного акцизу з тютюнових виробів наштовхнулася на неабиякий супротив органів місцевого самоврядування, оскільки відмова від цього податку передбачає скорочення доходів їхніх бюджетів. Навіть пропозиція щодо зарахування частини надходжень «стандартного» акцизного податку до місцевих бюджетів не знайшла підтримки на місцевому рівні через побоювання, що відповідний фінансовий потік 3 державного бюджету буде меншим від надходжень «роздрібного» акцизу.

У 2018 році Асоціація міст України запропонувала поєднати повне скасування роздрібного акцизу зі збільшенням частки зарахування надходжень податку на доходи фізичних осіб до місцевих бюджетів із 60 до 70 \%. Це усуне суперечність податкового законодавства України з вимогами ст. 1 Директиви Ради 2008/118/СС та збереже стабільну фінансову основу функціонування органів місцевого самоврядування.

Фахівці також пропонують як ще один фіскальний компенсатор для місцевих бюджетів удосконалення майнового оподаткування. Воно створить передумови для скасування цього виду акцизу. Фіскальний потенціал податку на майно в Україні, зокрема фізичних осіб, використовується не повністю. Наприклад, у 2016 р. співвідношення до ВВП податку на майно в Україні становило $1 \%$, тоді як у низці європейських країн воно сягало 5 \% (наприклад, у Бельгії - 3,6, Греції - 3,2, Іспанії - 2,7, Франції - 4,7, Великобританії 4,3\%). Водночас, у зв'язку з реформуванням органів ДФС України, функції адміністрування податків перейшли до регіональних управлінь, а замість районних і міжрайонних державних податкових інспекцій функціонують центри з обслуговування платників податків. Адміністрування місцевих податків тепер ускладнено об’єктивними причинами, оскільки часто здійснюється без ефективної комунікації між фіскальними органами і органами місцевого самоврядування, які приймають рішення щодо визначення ставок та бази оподаткування податками на майно.

Наразі існують проблеми, що становлять перешкоди для подальшого ефективного наповнення дохідної частини місцевих бюджетів за рахунок надходжень від реалізації тютюнових виробів та потребують вирішення і постійного контролю з боку держави:

1. Можливі законодавчі зміни можуть призвести до втрати місцевими бюджетами коштів від реалізації тютюнових виробів. Зокрема, Федерація роботодавців України звернулася до Уряду 3 пропозицією скасувати сплату суб'єктами господарювання роздрібного акцизу з тютюну як фіскально неефективного та складного в адмініструванні податку.

За даними Федерації роботодавців України, у 2018 р. місцеві бюджети мали отримати від цього податку 4,3 млрд. грн., а отримали лише 2,4 млрд. грн., що складає 45\%. Тому втрати місцевих бюджетів через скасування роздрібного акцизу з тютюну можуть скласти саме ці 2,4 млрд. грн. та призведуть до розбалансування багатьох бюджетів через відсутність компенсатора таких втрат.

Також у Верховній Раді України зареєстровано законопроект «Про внесення змін до Податкового кодексу України щодо удосконалення адміністрування місцевих податків та зборів» (№ 10154-1 від 20.03.2019 р.), яким, зокрема, також пропонується скасування норми справляння роздрібного акцизу 3 тютюну.

Складність адміністрування та ухилення від оподаткування - основні аргументи, що стосуються скасування акцизного податку з роздрібної реалізації тютюнових виробів. Але ж ці недоліки притаманні також і іншим видам податків (наприклад, недоотримання сум податку з доходів фізичних осіб місцевими бюджетами через нелегальне працевлаштування) та не можуть слугувати грунтовними підставами для його скасування.

В Асоціації міст України виступають проти скасування цього податку та пояснюють, що акцизний податок зараховується в повному обсязі до загального фонду бюджетів органів місцевого самоврядування та $є$ їх стабільним джерелом надходжень. Зменшення цих надходжень негативно позначиться на можливостях виконання органами місцевого самоврядування своїх повноважень з огляду на скорочення обсягу ресурсів. Адже завдяки коштам роздрібного акцизу органи місцевого самоврядування вперше за багато років суттєво збільшили видатки на оновлення комунальної інфраструктури та змогли здійснити значні обсяги робіт по будівництву та ремонту доріг, благоустрою, громадському транспорту, ремонту будівель, заходах з енергоефективності, освітленню вулиць, покращенню стану ЖКГ та інші напрями. Роздрібний акциз є також і інструментом стимулювання до інтенсифікації місцевого економічного розвитку та об’єднання громад. Отже, зі скасуванням акцизного податку з роздрібної реалізації тютюнових виробів чимало громад будуть позбавлені можливості вирішувати важливі проблеми власного розвитку.

2. Нелегальний продаж тютюнових виробів зменшує надходження до місцевих бюджетів. 
За даними Державної фіскальної служби України, податок не платять майже в кожному другому випадку кінцевої реалізації сигарет та ій не вдається проконтролювати 80 тисяч точок роздрібного продажу.

31 липня 2018 р. в Україні почали діяти нові правила маркування тютюнових виробів акцизними марками. Такі дії мають вплинути на зменшення обсягів нелегального продажу. Посилення контролю над виробництвом, продажем та логістикою тютюнових виробів є метою цих змін.

На початку 2018 р. ДФС перевірила один з філіалів одного з тютюнових виробників і виявила там 452 тис. пачок сигарет 3 фільтром, обклеєних акцизними марками для інших тютюнових виробів, які оподатковуються за меншими ставками.

За підрахунками ДФС, податкові зобов'язання було занижено щонайменше на 3,5 млн грн. Як свідчать оперативні матеріали ДФС, під час обшуку було вилучено великі партії сигарет марок Strong та Lifa. Tакож близько 30-40 \% акцизного податку з роздрібного продажу тютюнових виробів не декларуються.

3. Відсутність Плану заходів до Стратегії у сфері протидії незаконному виробництву та обігу тютюнових виробів на період до 2021 р., яка була ухвалена постановою Уряду 23 серпня 2017 р., 3 метою протидії незаконному виробництву та обігу тютюнових виробів. Це є причиною того, що ця Стратегія не діє.

Також стосовно вирішення питання протидії нелегальному роздрібному обігу тютюнових виробів у ДФС триває робота над запровадженням автоматизованої системи контролю обігу підакцизних товарів «Електронна акцизна марка», яка покликана унеможливити їх нелегальний обіг.

В Україні вже є приклади вирішення проблем стосовно контролю за обігом підакцизних товарів. Головне управління ДФС в Одеської області спільно з правоохоронними органами запустили у 2018 р. пілотний проект - мобільний додаток «Легальний акциз». Цей електронний сервіс покликаний по-перше, інформувати громадян про наявність ліцензій на продаж такого виду продукції, а по-друге, створює можливість оперативно повідомляти про факти можливих порушень.

Висновки та перспективи подальших досліджень. Інтеграція у світовий економічний простір вимагає від України адаптації податкового законодавства до норм ЄС. Має проводитися виважена податкова політика для недопущення розбалансованості місцевих бюджетів. Зі скасуванням акцизного податку з роздрібної реалізації тютюнових виробів громади втратять і ту частину коштів, що отримують від цих надходжень, та будуть позбавлені можливості покращувати інфраструктуру за рахунок використання цих надходжень, оскільки не всі вони є фінансово спроможними.

\section{Список використаної літератури:}

1. Асоціація міст України [Електронний ресурс]. - Режим доступу : www.auc.org.ua/novyna/golova-amuvklychko-zvernuvsya-do-premyer-ministra-shchodo-nedopushchennya-skasuvannya.

2. Діалектика реформування акцизного оподаткування тютюнових виробів в Україні: євроінтеграційний аспект / за заг. ред. B.I. Коротуна. - Ірпінь : Університет ДФС України, 2018. - 100 с. [Електронний ресурс]. Режим доступу : http://ndi-fp.nusta.edu.ua/files/doc/2018_brochure.pdf.

3. Цензор.нет [Електронний ресурс]. censor.net.ua/blogs/3109795/dfs_bezporadna_schodo_admnstruvannya_rozdrbnogo_aktsizu_z_tyutyunovih_virobv _45_kntsevo_realzats_v_tn.

4. Економічна правда [Електронний ресурс]. - Режим доступу : www.epravda.com.ua/publications/2018/07/2/638299.

5. Рубрика [Електронний ресурс]. - Режим доступу : rubryka.com/2019/01/16/ukrtyutyun-borotba-z-nelegalnymobigom-sygaret.

6. Уніан [Електронний ресурс]. - Режим доступу : https://economics.unian.net/finance/10240740-germaniyarassmatrivaet-vozmozhnost-okazaniyafinansovoy-pomoshchi-turcii-smi.html.

7. Верховна Рада України [Електронний ресурс]. http://w1.c1.rada.gov.ua/pls/zweb2/webproc6_current?id=\&pid069=200.

8. Озерчук O.B. Напрями удосконалення акцизного оподаткування в Україні згідно вимог законодавства ЄC / $O . B$. Озерчук // Ефективна економіка : електронний журнал [Електронний ресурс]. - Режим доступу : http://www.economy.nayka.com.ua/?op=1\&z=5336.

9. Опарін В.М. Фінанси (загальна теорія) : навч. посібник / В.M. Опарін. - 2-ге вид., доп. і перероб. - К. : КНЕУ, 2002. $-240 \mathrm{c}$.

10. Фінанси : підручник / за ред. С.І. Юрія, В.М. Федосова. -2-ге вид., перероб. і доп. - К., 2012. - 687 с.

\section{References:}

1. Asociacija mist Ukrai'ny, [Online], available at: www.auc.org.ua/novyna/golova-amu-vklychko-zvernuvsya-dopremyer-ministra-shchodo-nedopushchennya-skasuvannya

2. Korotun, V.I. (ed.) (2016), Dialektyka reformuvannja akcyznogo opodatkuvannja tjutjunovyh vyrobiv v Ukrai'ni: jevrointegracijnyj aspekt, Universytet DFS Ukrai'ny, Irpin',100 p., [Online], available at: http://ndifp.nusta.edu.ua/files/doc/2018_brochure.pdf 
3. Cenzor.net,

[Online],

available

at: censor.net.ua/blogs/3109795/dfs_bezporadna_schodo_admnstruvannya_rozdrbnogo_aktsizu_z_tyutyunovih_virobv _45_kntsevo_realzats_v_tn

4. Ekonomichna pravda, [Online], available at: www.epravda.com.ua/publications/2018/07/2/638299

5. Rubryka, [Online], available at: rubryka.com/2019/01/16/ukrtyutyun-borotba-z-nelegalnym-obigom-sygaret

6. Unian, [Online], available at: https://economics.unian.net/finance/10240740-germaniya-rassmatrivaet-vozmozhnostokazaniyafinansovoy-pomoshchi-turcii-smi.html

7. Verhovna Rada Ukrai'ny, anline], available http://w1.c1.rada.gov.ua/pls/zweb2/webproc6_current?id=\&pid069=200

8. Ozerchuk, O.V., «Naprjamy udoskonalennja akcyznogo opodatkuvannja v Ukrai'ni zgidno vymog zakonodavstva JeS», Efektyvna ekonomika, elektronnyj zhurnal, [Online], available at: http://www.economy.nayka.com.ua/?op=1\&z=5336

9. Oparin, V.M. (2002), Finansy (zagal'na teorija), navch. posibnyk, KNEU, K., 240 p.

10. Jurij, S.I. and Fedosova,V.M. (ed.) (2012), Finansy, pidruchnyk, K., 687 p.

Бахур Надія Вікторівна - головний консультант відділу регіональної політики Національного інституту стратегічних досліджень.

Наукові інтереси:

- економічний розвиток регіонів України.

Стаття надійшла до редакції 27.06.2019. 